\title{
Human Monoclonal Antibodies: On the Menu of Targeted Therapeutics Against COVID-19
}

\author{
Junsen Chen ${ }^{1} \cdot$ Rui Huang ${ }^{1} \cdot$ Yiwen $\mathrm{Nie}^{1} \cdot$ Xinyue Wen ${ }^{1} \cdot$ Ying $\mathrm{Wu}^{1,2}$ (D)
}

Received: 24 August 2020 / Accepted: 11 November 2020/ Published online: 4 January 2021

(c) Wuhan Institute of Virology, CAS 2020

\begin{abstract}
Coronavirus disease 2019 (COVID-19), reminiscent of the severe acute respiratory syndrome (SARS) outbreak in 2003, has been a tragic disaster to people all over the world. As there is no specific drug for COVID-19, neutralizing antibodies are attracting more and more attention as one of the most effective means to combat the pandemic. Here, we introduced the etiological and serological characteristics of COVID-19, discussed the current stage of development of human monoclonal antibodies against SARS-CoV-2 and summarized the antigenic epitopes in the S glycoprotein, which may deepen the understanding of the profile of immune recognition and response against SARS-CoV-2 and provide insight for the design of effective vaccines and antibody-based therapies.
\end{abstract}

Keywords COVID-19 $\cdot$ mAbs $\cdot$ S glycoprotein $\cdot$ Epitopes

By Oct. 29, 2020, in a matter of 10 months since the beginning of the COVID-19 outbreak, more than 43,000,000 confirmed cases of COVID-19 had been reported, with more than 1,100,000 deaths (WHO 2020). The origin and intermediate host of SARS-CoV-2, the virus responsible for COVID-19, have not been identified yet. However, it has been confirmed that this virus is mainly transmitted by respiratory droplets and direct contact (Liu $\mathrm{Y}$ et al. 2020). Moreover, SARS-CoV-2 viral nucleic acid was detected in the feces of patients (Wu Y et al. 2020), which has been observed in other coronavirus infection cases (Guan et al. 2015; Mackay and Arden 2015), and a rise in immunoglobulin $\mathrm{M}$ (IgM) antibody levels was confirmed in newborns, suggesting that SARS-CoV-2 can also be transmitted through the fecal-mouth route and vertically from mother to child (Dong et al. 2020). Humans of all ages are susceptible to SARS-CoV-2 infection, which is spreading more efficiently than influenza. Therefore, it is

Ying Wu

yingwu@whu.edu.cn

1 State Key Laboratory of Virology, School of Basic Medical Sciences, Wuhan University, Wuhan 430072, China

2 Hubei Province Key Laboratory of Allergy and Immunology, Wuhan 430072, China crucial and pressing to search for effective treatment strategies to cope with such an unprecedented health emergency.

There are currently no approved drugs or vaccines for COVID-19, highlighting the huge unmet medical need to develop treatments. Convalescent plasma therapy has been proven successful in conferring protection against SARS$\mathrm{CoV}$, MERS-CoV, avian influenza, and Ebola virus infections, considerably alleviating clinical symptoms and reducing mortality (Bloch et al. 2020). The available data also support the feasibility of this treatment for SARSCoV-2 (Devasenapathy et al. 2020). However, a largescale convalescent plasma transfusion program is conditioned by the limited availability of convalescent plasma and the lack of appropriate risk assessment (Shi et al. 2020). On the other hand, neutralizing monoclonal antibodies (mAbs) have attracted extensive interest as promising candidates to fight against emerging viruses. The administration of mAbs for passive immunization can provide immediate and specific protection and complement the development of preventive vaccines, thus potentially having a significant impact on the control of the COVID-19 pandemic. The successful use of mAb therapy (mAb114) during the Ebola virus outbreak highlighted the effectiveness and safety of mAbs (Corti et al. 2016). More importantly, the therapeutic potential of antibodies targeting 
coronaviruses was well recognized during the SARS outbreak (Wang C et al. 2020).

\section{Etiological Characteristics of COVID-19}

The Coronaviridae family is subdivided into four genera: $\alpha, \beta, \gamma$, and $\delta$ (Fehr and Perlman 2015). Among the seven coronaviruses that have been reported to infect humans, HCoV-229E and HCoV-NL63 belong to genus $\alpha$; the remaining five viruses are all classified into genus $\beta$, including HCoV-OC43, HCoV-HKU1, SARS-CoV, MERS-CoV, and SARS-CoV-2. Specifically, infections of HCoV-229E, HCoV-NL63, HCoV-OC43, and HCoVHKU1 mainly cause mild respiratory diseases, while infection by SARS-CoV-2 may eventually lead to severe pneumonia and death, similarly to infection by SARS-CoV $(\sim 10 \%$ mortality rate) and MERS-CoV $(\sim 36 \%$ mortality rate), both of which have induced worldwide outbreaks in the past two decades (Zaki et al. 2012; Ying et al. 2015).

Previous studies revealed that the SARS-CoV-2 genome has 29,891 nucleotides and encodes a single open reading frame (ORF) flanked by two untranslated regions (UTRs). Two-thirds of the genome are proteolytically cleaved into 16 putative nonstructural proteins (nsps) and four main structural proteins, which are the spike protein $(\mathrm{S})$, membrane protein $(\mathrm{M})$, envelope protein $(\mathrm{E})$, and nucleocapsid $(\mathrm{N})$ and are encoded at the $3^{\prime}$ end of the viral genome (Chan et al. 2020).

Host cell entry is mediated by the $\mathrm{S}$ protein by binding of its S1 subunit to angiotensin-converting enzyme 2 (ACE2) receptors on the cell surface, which subsequently triggers conformational changes on the S2 subunit, thus allowing the virus to enter the host cells via endocytosis. $\mathrm{S} 1$ is composed of the N-terminal domain (NTD) and receptor-binding domain (RBD), which is crucial to determine tissue tropism and host ranges (Walls et al. 2020). SARS-CoV-2 uses ACE2 for entry and the serine protease TMPRSS2 for S protein priming, which facilitates SARS-CoV-2 entry into host cells (Markus et al. 2020; Dong et al. 2020). After entry, SARS-CoV-2 is uncoated and the single positive $(+)$ strand RNA is released into the cytoplasm and subsequently translated to produce polypeptides, which are cleavaged into nsps by papain-like protease and Mpro or 3CLpro. These nsps include helicase and RNA-dependent RNA polymerase (RdRp), which will participate in the process of RNA synthesis. As well as nsps, structural and other proteins are encoded by viral genome after RNA synthesis. Eventually, the structural protein and genome are assembled into a new virion and released by exocytosis (Sanders et al. 2020).

\section{Serological Characteristics of COVID-19 Patients}

Currently, the serological characteristics of COVID-19 patients are partially documented. $\mathrm{Xu}$ et al. examined the IgM and IgG levels in 17,368 individuals, including patients, related hospital workers, and residents in an involved community, to assess the cumulative prevalence of SARS-CoV-2 infection in China (Xu et al. 2020). They reported that the seropositivity in Wuhan varied between $3.2 \%$ and $3.8 \%$ and in a subcohort of 242 patients with infection confirmed by a viral nucleic acid RT-PCR test, the cumulative seroprevalence rates of IgM and IgG antibodies against the recombinant antigens containing the nucleoprotein and a peptide from the $\mathrm{S}$ protein of SARSCoV-2 on the 7th day after the onset of symptoms were $44 \%$ and $56 \%$, respectively, and both reached over $95 \%$ by day 20 and day 16, respectively (Xu et al. 2020). Moreover, Zhao et al. showed that among 173 patients the seroconversion rate for total antibodies ( $\mathrm{Ab}), \mathrm{IgM}$, and IgG within one week since the onset was $93.1 \%, 82.7 \%$, and $64.7 \%$, respectively, and after two weeks the proportion greatly increased to $100.0 \%(\mathrm{Ab}), 94.3 \%$ (IgM), and $79.8 \%$ (IgG) (Zhao et al. 2020).

Wang et al. further reported that mean antibody neutralization titers against SARS-CoV-2 live virus were $\sim$ sevenfold higher in the sicker patients and that patients with severe COVID-19 had more robust binding antibodies to both the $\mathrm{N}$ protein and $\mathrm{S}$ trimer (Wang $\mathrm{P}$ et al. 2020). Even though antibodies against the SARSCoV-2 N protein do not provide protective immunity against infection (Gralinski and Menachery 2020), specific antibodies against the $\mathrm{S}$ protein do (Gao et al. 2020). Additionally, another study demonstrated that RBDspecific $\operatorname{IgG}$ accounts for half of the $\mathrm{S}$ protein-antibody response in COVID-19 patients during recovery, indicating that RBD is the primary immunogen (Liu L et al. 2020).

Nevertheless, sera collected from SARS and COVID-19 patients exhibited limited cross-neutralization, as demonstrated by Hou et al. using luciferase reporter viruses. The study showed that convalescent COVID-19 sera failed to cross-neutralize SARS-CoV in vitro and rare cross-neutralizing antibodies were generated after SARS-CoV-2 infection (Hou et al. 2020), which was also reported in other studies (Ou et al. 2020; Anderson et al. 2020). Thus, recovery from SARS-CoV-2 infection may not confer resistance to SARS-CoV and vice versa.

Additionally, Okba et al. detected MERS-CoV-S crossreactive antibodies in the serum of a COVID-19 patient, but not MERS-CoV-S1 cross-reactive antibodies, which is consistent with their earlier findings for MERS-CoV serology (Okba et al. 2020). This finding revealed a higher 
specificity of S1 for SARS-CoV-2 antibodies, which could be due to the high degree of conservation in the CoV S2 subunit compared to $\mathrm{S} 1$. Thus, $\mathrm{S} 1$ is more specific than $\mathrm{S}$ as an antigen for SARS-CoV-2 serological diagnosis.

Clinical application of convalescent plasma in COVID19 patients demonstrated that neutralizing antibodies provide important specific immune defense against viral infections. It has been reported neutralizing antibodies in asymptomatic patients decay faster than symptomatic individuals (Long et al. 2020; Ibarrondo et al. 2020). In a large cohort investigation, Stefansson et al. tested 2102 samples collected from 1237 persons in Iceland, and observed antibodies persisted for as long as 4 months after diagnosis (Baum et al. 2020). Moreover, 14 serum specimens from 17 COVID-19 patients at 6-7 months post-infection showed significant neutralizing activities in Tan's research (Tan et al. 2020). It is necessary to conduct further studies about the dynamics of neutralizing antibodies and the duration of humoral immunity. The differences among these researches might be resulted from many factors, such as enrolled cases of different ethnic groups and geographical regions, varied sampling and testing methods and so on.

Collectively, these findings provide strong empirical support for the serological diagnosis and management of COVID-19 patients, as well as antigen selection for candidate vaccines and targeted antibody development.

\section{Discovery and Development of Therapeutic Neutralizing Antibodies}

Therapeutic neutralizing antibodies need to go through a long process from isolation to clinical application. In vitro assays of neutralizing activity, in vivo evaluation of protective effect, and safety and clinical trials are necessary steps for antibody development. Researchers are endeavoring to develop such mAbs or their functional fragments as prophylactic or therapeutic agents to prevent or treat SARS-CoV-2 infection. Therefore, compared to the usual timelines, the development of $\mathrm{mAbs}$ in this pandemic setting could be reduced in 5-6 months. Moreover, the previous researches on SARS-CoV and MERS-CoV antibodies provide a basis for these studies (Wang HY et al. 2020).

47D11 was the first SARS-CoV-2-neutralizing human monoclonal antibody to be reported, which was screened from readily available hybridoma libraries of genetically modified mice that had been immunized with SARS-CoV and MERS-CoV S proteins (Wang C et al. 2020). In vitro experiments showed 47D11 could neutralize authentic SARS-CoV and SARS-CoV-2 with $\mathrm{IC}_{50}$ values of $0.19 \mu \mathrm{g} /$ $\mathrm{mL}$ and $0.57 \mu \mathrm{g} / \mathrm{mL}$, respectively, indicating that antibodies isolated from SARS survivors may play a huge role in our fight against SARS-CoV-2 (Table 1).

Many neutralizing antibodies derived from B cells of patients infected with SARS-CoV have been reported until now, such as S309 (Pinto et al. 2020), CR3022, CR3014 (Yuan et al. 2020b), 80R (Hwang et al. 2006), and m396 (Prabakaran et al. 2006), some of which showed potent cross-reactivity to SARS-CoV-2. S309 can neutralize both SARS-CoV and SARS-CoV-2, while CR3022, CR3014, $80 \mathrm{R}$, and $\mathrm{m} 396$ can only neutralize SARS-CoV. $\mathrm{IC}_{50}$ value of S309 for SARS-CoV-2 neutralization was $0.079 \mu \mathrm{g} / \mathrm{mL}$. Interestingly, CR3022 also showed cross-reactivity with SARS-CoV-2 RBD (Table 1).

In addition, Wrapp et al. obtained a single-domain antibody (VHH), VHH-72, derived from a llama immunized with SARS-CoV and MERS-CoV S proteins, that can bind tightly to the RBD region of SARS-CoV S protein and neutralize SARS pseudoviruses. By further engineering this VHH into a bivalent Fc-fusion protein, they showed that this novel bivalent molecule could also neutralize SARS-CoV-2 pseudoviruses with an $\mathrm{IC}_{50}$ of approximately $0.2 \mu \mathrm{g} / \mathrm{mL}$ (Wrapp et al. 2020a) (Table 1).

As with other human pathogens, mAb can be easily isolated from the B cells of patients infected with SARS$\mathrm{CoV}-2$ by the antigenic protein bait. Thus, the protein bait needs to be functionally relevant and pure enough to isolate antibodies that are relevant to the epitopes on the native spike. The RBD domain and S1 subunit of SARS-CoV-2 are often selected as protein bait for fishing out the antibodies. Severe cases seem to have a much higher neutralizing antibody response and hence more likelihood of obtaining potent neutralizing antibodies (Zhao et al. 2020). However, it is unclear about the relationship between the severity of diseases and antibody response. It will take a while to figure out the cause and consequence of the two.

$\mathrm{Ju}$ et al. first analyzed the immune responses of eight SARS-CoV-2-infected patients after exposure to virus stimulation, including the level of viral-specific antibodies in plasma and the proportion of specific B cells in memory cells, finding that the antibody response levels among these infected patients varied greatly (Ju et al. 2020). Further, this group isolated 206 monoclonal antibodies capable of recognizing SARS-CoV-2 RBD and obtained their paired heavy- and light-chain gene sequences. Using a pseudovirus evaluation system, the antibody inhibition rate of 12 strains exceeded $50 \%$ and that of the other seven strains exceeded $80 \%$. Among them, P2C-1F11 and P2B-2F6 were elite antibodies with $\mathrm{IC}_{50}$ of $0.03 \mu \mathrm{g} / \mathrm{mL}$ and $0.05 \mu \mathrm{g} / \mathrm{mL}$, respectively (Table 1).

Moreover, Shi et al. used SARS-CoV-2 S protein recombinant $\mathrm{RBD}$ as bait to screen specific memory $\mathrm{B}$ cells in peripheral blood mononuclear cells (PBMCs) from peripheral blood of convalescent patients with COVID-19 


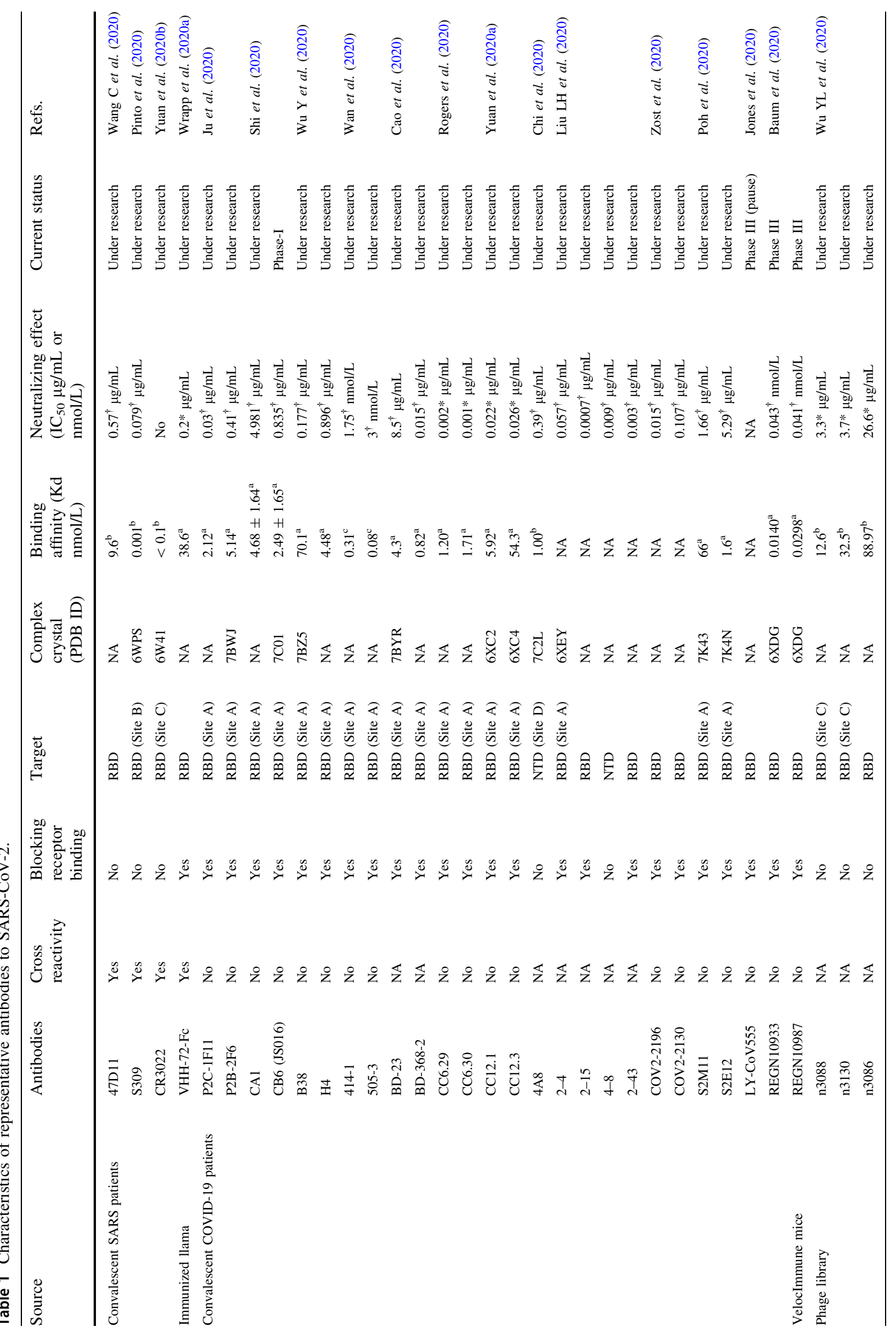




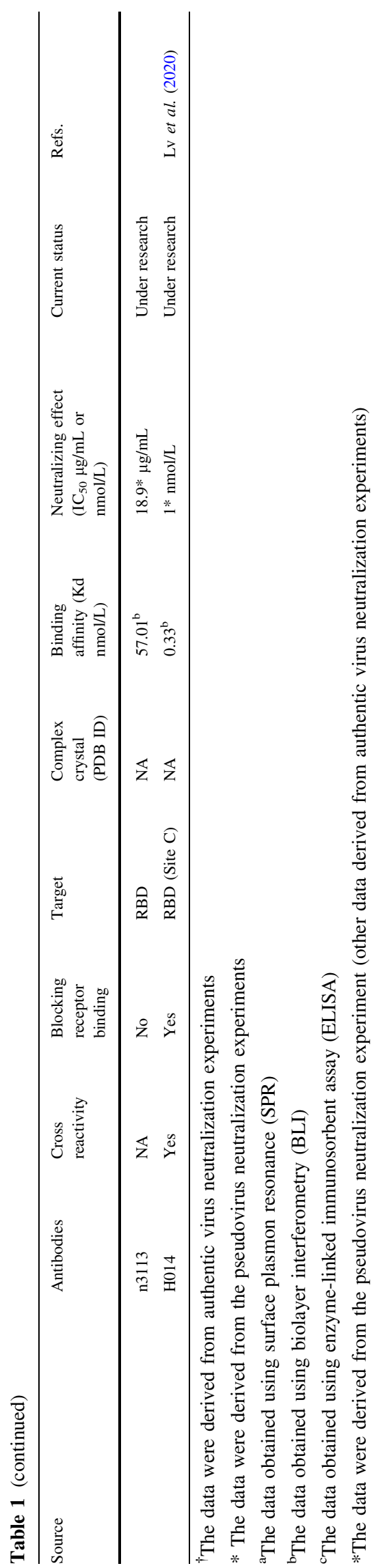

(Shi et al. 2020). The variable region sequences of these B cell receptors were cloned into a vector containing a constant region to produce a series of $\mathrm{IgG}$ antibodies. Among them, CB6 was selected for testing in animal models and the results showed that this antibody not only reduced the virus titer but also inhibited the pathological lung damage in the monkeys challenged with SARS-CoV-2.

Meanwhile, a team led by George $\mathrm{Fu}$ Gao isolated four human mAbs (B38, H4, B5 and H2) from a rehabilitated patient, all of which have shown in vitro neutralization of SARS-CoV-2 and two of which (B38 and H4) block the binding of RBD to the cellular receptor ACE2 (Wu et al. 2020b) (Table 1).

On the other hand, Wan et al. enriched more than 1000 antigen-specific B cells in plasma from 11 COVID-19 rehabilitation patients by using the recombinant $\mathrm{S} 1$ or RBD antigen of SARS-CoV-2 and cloned 729 pairs of naturally paired antibody genes of single B cells (Wan et al. 2020). The team mainly reported 11 different neutralizing antibody sequences, eight of which showed an $\mathrm{IC}_{50}$ within $10 \mathrm{nmol} / \mathrm{L}$ and the best one, 414-1, with an $\mathrm{IC}_{50}$ of $1.75 \mathrm{nmol} / \mathrm{L}$. Besides, 553-15 could be combined with other neutralizing antibodies and increase their neutralizing ability (Table 1).

Meanwhile, Cao et al. used high-throughput cell sequencing to identify 14 highly active neutralizing antibodies from a screening of 8558 viral protein-binding antibody sequences, the most effective of which was a neutralizing antibody called BD-368-2 (Cao et al. 2020). Unlike traditional methods, large-scale data obtained from high-throughput single cell can help researchers observe the clonal enrichment of B cells before antibody expression in vitro and calculate the degree of enrichment based on the number of cloned cells observed. The researchers suggest that enriched B cell clones are more likely to produce novel binding SARS-CoV-2 neutralizing antibodies with high affinity. In addition, by using bioinformatics methods to predict the structure of $\mathrm{CDR} 3 \mathrm{H}$, researchers found $\mathrm{mAbs}$ with highly similar CDR3H structures to the SARS-CoV neutralizing antibody $\mathrm{m} 396$ showed a high neutralization potency for SARS-CoV-2. The largely conserved combination of the VDJ gene segment and the likely overlapping epitopes of those mAbs suggest the existence of stereotyped B cell receptors against SARS-CoV-2 (Cao et al. 2020). A new study supports this idea: Yuan et al. compiled a list of 294 SARS-CoV-2 RBD-targeting antibodies where information on IGHV gene usage is available and found that IGHV3-53 is the most frequently used IGHV gene among these antibodies (Yuan et al. 2020a) (Table 1).

Furthermore, Chi et al. isolated and identified mAbs from 10 recovering COVID-19 patients. Three of these mAbs showed neutralizing activity against SARS-CoV-2. 4A8 showed high potency against both SARS-CoV-2 and 
its pseudovirus and it works by binding to a unique region in the NTD rather than RBD of the S protein (Chi et al. 2020) (Table 1).

To study the antibody response against SARS-CoV-2 and discover mAbs, the Scripps research team adapted their pipeline to rapidly isolate and characterize mAbs from convalescent donors (Rogers et al. 2020). A group of SARS-CoV-2 donors who had previously tested positive on the swab test was recruited for PBMC and plasma collection. Assessed by the neutralizing activity of convalescent serum against SARS-CoV and SARS-CoV-2 and selected eight donors for $\mathrm{mAb}$ discovery. They classified single antigen-specific memory B cells and recovered and cloned the corresponding variable genes using a high-throughput production system that could achieve antibody expression and identification within 2 weeks. More than $1000 \mathrm{mAbs}$ were isolated from three convalescent donors by memory B cell selection using SARS-CoV-2 S or RBD recombinant proteins. Notably, the most potent neutralizing antibodies were those directed to the core region of RBD, known as the receptor-binding motif (RBM), including two antibodies, CC6.29 and CC6.30, that neutralize SARS-CoV-2 pseudovirus with an $\mathrm{IC}_{50}$ of $2 \mathrm{ng} / \mathrm{mL}$ and $1 \mathrm{ng} / \mathrm{mL}$, respectively (Table 1).

Liu LH et al. (2020) isolated 61 SARS-CoV-2 neutralizing antibodies from 5 severe COVID-19 patients. Among them, nine antibodies showed very high neutralization potency, with $\mathrm{IC}_{50}$ values ranging from 0.7 to $9 \mathrm{ng} / \mathrm{mL}$. The nine antibodies are diverse and can be divided into three categories, four against RBD $(2-15,2-7,1-57$, and 1-20), three against NTD (2-17, 5-24, and 4-8), and two against the undetermined region of S trimer (2-43 and 2-51). Notably, $2-15$, binding to the top region of RBD, exhibits the most competitive against ACE2 and the most neutralizing activity to SARS-CoV-2 (Table 1).

In addition, Wu YL et al. (2020) developed a new technique to screen and reconstruct the full human heavychain variable region antibody skeleton. Using this technique, a whole human nanometer antibody library based on natural germline genes was designed. The RBD domain and S1 protein subunit of SARS-CoV-2 were selected as antigens, and nano-antibodies targeting multiple epitopes were selected from the antibody library. Among them, antibodies n3130, n3088, n3086, and n3113 showed moderate neutralization activities, inhibiting SARS-CoV-2 pseudovirus infection in a dose-dependent manner with $\mathrm{IC}_{50}$ values of $26.6,18.9,3.3$, and $3.7 \mu \mathrm{g} / \mathrm{mL}$, respectively. The combination of $n 3088$ or $n 3130$ with $n 3113$ showed synergistic neutralization of SARS-CoV-2, with $\mathrm{IC}_{50}$ values of 0.51 and $0.70 \mu \mathrm{g} / \mathrm{mL}$, respectively. Similarly, Lv et al. recently established a coronavirus antibody library by using phage display technology and identified an antibody, H014, with broad-spectrum neutralization of the coronavirus family by high-throughput screening (Lv et al. 2020). Pseudovirus neutralization assays revealed that $\mathrm{H} 014$ has a potent neutralizing activity, with an $\mathrm{IC}_{50}$ of $3 \mathrm{nmol} / \mathrm{L}$ and $1 \mathrm{nmol} / \mathrm{L}$ against SARS-CoV-2 and SARSCoV pseudoviruses, respectively (Table 1).

With the advancement of research, many antibody drugs have entered clinical trials. It is worth mentioning that on June 5, 2020, the China Food and Drug Administration officially approved the first clinical trial of a novel therapeutic antibody, mAb CB6 derived from a convalescent patient, which is now at the edge of phase I. Additionally, on June 11, 2020, REGN announced the clinical trial of its antibody cocktail therapy for the treatment and prevention of COVID-19. It contains two antibodies, REGN10933 and REGN10987, which were obtained by regeneration from the VelocImmune transgenic mouse platform and COVID19 rehabilitation patient blood based on the screening of the efficacy and binding ability of the S protein (Baum et al. 2020). Moreover, more than 10 antibody drugs such as LY-CoV555 (phase III), AZD7442 (phase I), CT-P59 (phase I) and TY027 (phase I) are already in clinical trials (https://clinicaltrials.gov/), giving us the hope of dealing with the COVID-19.

\section{Characteristics of the Spike Glycoprotein}

The spike (S) glycoprotein of SARS-CoV-2, which forms homotrimers protruding from the viral surface, can mediate virus entry into host cells (Wrapp et al. 2020b). The S protein is a class I fusion protein that consists of two subunits, S1 and S2. The S1 subunit is responsible for binding to host cell receptors and the S2 subunit mediates the fusion of viral and cellular membranes (Wrapp et al. 2020b).

Besides its pivotal role for virus entry, $\mathrm{S}$ protein is also the main target of neutralizing antibodies and the focus of therapeutic and vaccine design efforts. The $\mathrm{S}$ protein amino acid sequence homology between SARS-CoV-2 and SARS-CoV is $80 \%$ and between SARS-CoV-2 and the bat SARS-related CoV (SARSr-CoV) RaTG13, 97.2\% (Zhou et al. 2020). Previous studies revealed that SARS-CoV-2 has a higher affinity for hACE2 than SARS-CoV. Compared with the RBD of SARS-CoV, the binding conformation of ACE with SARS-CoV-2 RBD is more compact. In addition, the substitution of several residues in SARSCoV-2 RBD can make two virus-binding hotspots at the RBD-ACE2 interface more stable. Therefore, SARS-CoV2 RBD has a higher binding affinity for ACE2 (Shang et al. 2020). As RBD-specific antibodies have a brilliant neutralizing ability for different virus strains, SARS-CoV-2 RBD can provide a basis for the study of antibody targets 


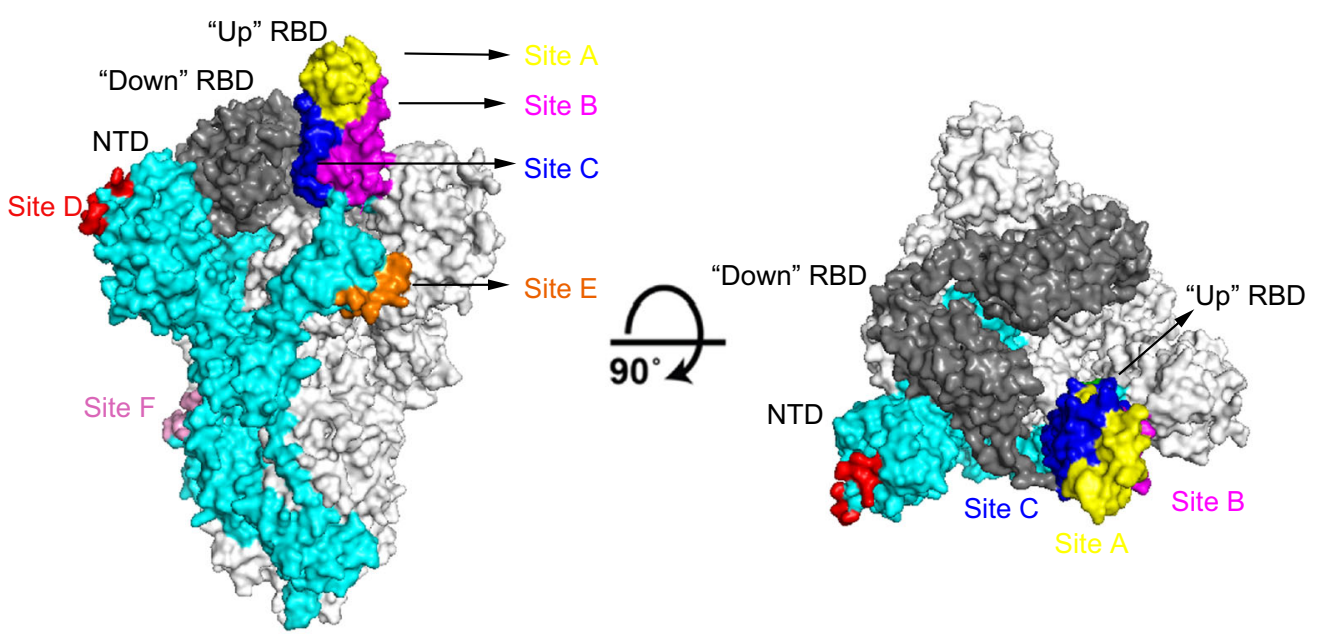

Fig. 1 Structure of SARS-CoV-2 S trimer in the prefusion conformation displayed as molecular surfaces. Side (left) and top (right) views of the S trimer with a single RBD in the up" conformation is shown (PDB ID 6VYB). The monomer corresponding to the "up" conformation is marked as cyan, and the monomers corresponding to

for highly specific and high-affinity antibodies (Wrapp et al. 2020b).

$\mathrm{S}$ glycoprotein is in a pre-fusion conformation before contacting the cell receptor and can promote virus fusion with the host cell membrane through several structural rearrangements (Wrapp et al. 2020b). The binding of S protein to the host receptor destroys the stability of the prefusion trimer, resulting in the shedding of the S1 subunit and the transformation of the S2 subunit into a highly stable post-fusion conformation. It should be noted that in order to attach the host receptor, the RBDs in S1 subunits require hinge-like conformational movements, with one RBD fully exposing the determinants of receptor binding, while the other two are hidden. Thus, the predominant state of the trimer exists as one "up" (receptor-accessible) and two "down" (receptor-inaccessible) conformations (Fig. 1).

\section{The Antigenic Epitopes in the S Trimer}

$\mathrm{RBM}$, the core region of the RBD, is the binding site of hACE2 (Shang et al. 2020). The X-ray crystal structure and Cryo-EM structure reported by recent studies have shown that antibodies CB6 (Shi et al. 2020), P2B-2F6 (Ju et al. 2020), BD23 (Cao et al. 2020), B38 (Wu et al. 2020b), 2-4 (Liu LH et al. 2020) and S2E12 (Poh et al. 2020) are all targeted to this region. These epitopes are clustered at the top of the S protein. When the S protein is in the "down" configuration, these epitopes are partially covered by the adjacent RBD. When the S protein is in the "up" configuration, they are completely liberated. This explains why the "down" state are marked as gray (RBD are marked as dark gray). Site A is highlighted in yellow, site B is highlighted in magenta, site $\mathrm{C}$ is highlighted in blue, site $\mathrm{D}$ is highlighted in red, site $\mathrm{E}$ is highlighted in orange, site $\mathrm{F}$ is highlighted in pink.

hACE2 and some antibodies can only bind to the "up" conformation. To better describe these binding epitopes, we denominate this region site A (residues $420-426$ and 431-502) (Fig. 1). The buried RBD surface area of CB6 is $1088 \AA$ and both the $\mathrm{VH}$ and VL of this antibody are heavily involved in antigen binding, explaining its superior affinity. P2B-2F6 binds to the RBD with a buried surface of $626 \AA$, involving 14 heavy- and three light-chain residues. The epitope residues include K444, G446, G447, N448, Y449, N450, L452, V483, E484, G485, F490, and S494. However, the only overlapping residues recognized by P2B-2F6 and hACE2 are G446 and Y449, largely due to angle differences as they approach the RBD. This also explains why P2B-2F6 can bind to both "up" and "down" conformations without clashing with the other S protomer. According to the results of 3D reconstruction by Cryo-EM, a single BD-23Fab is observed per $\mathrm{S}$ trimer with an "up" conformation, and only the $\mathrm{VH}$ of $\mathrm{BD}-23$ is involved in binding to the RBD. Particularly, the binding is also facilitated by an N-linked glycan on N165 of adjacent protomer NTD. Just like CB6, both the VH and VL of B38 participate in antigen combination and their buried surface area is $713.9 \AA$ and $497.7 \AA$, respectively. This wide range of binding patterns predicts their stronger binding and neutralizing activity. Although the RBD-binding epitopes of these antibodies are slightly different, they can all block binding to ACE2 by occupying the RBM, even if at different degrees. However, because of the variability of this region between SARS-CoV-2 and other coronaviruses, antibodies that bind to site $\mathrm{A}$ are generally not cross-active. Undeniably, the main problem for these antibodies is how to avoid virus escape. 
Another major antigenic site is shared by both the "up" and "down" conformations, which we named site B (residues 326-366) (Fig. 1); it is the target of antibody S309 (Pinto et al. 2020). Noticeably, S309 binds better to the "down" conformation than to the "up" conformation, possibly because the flexibility of the "up" conformation of the $\mathrm{S}$ trimer affects its binding. Site B harbors a conservative region in the RBD (residues 333-362) as well as a small overlap of RBM regions (residues 440-444) between SARS-CoV and SARS-CoV-2, which may account for the similar affinity of S309 for these two viruses.

Unlike S309, the epitope of CR3022, a neutralizing antibody obtained from a SARS convalescent patient and cross-reacting with SARS-CoV-2 S protein, is only accessible when at least two of the RBDs in the $S$ trimer are in the "up" conformation (Yuan et al. 2020b). This specific epitope is located on the $S$ trimeric interface, consisting of three segments in the primary sequence (residues 369-392, 427-430, and 516-520). H014 also only binds to the RBD in the "up" conformation. The epitope residues include S383, T387, D405, V407, A411, P412, V503, and Y508 (Lv et al. 2020). These two epitopes are partially overlapped and both are located on the inner region of RBD. This inner region is not exposed in the "down" conformation. In this case, we call this region site C (residues 367-419, 427-430, and 503-520) (Fig. 1). It is interesting to note that, even when one RBD in the SARSCoV-2 S trimer is in the "up" conformation, the binding of CR3022 to the RBD can still be sterically hindered. According to the structural model analysis, steric hindrance is resolved if the targeted RBD is slightly rotated in the "double-up" conformation. Though site C is a cross-reactive site, CR3022 likely binds more tightly to SARS-CoV because its epitope harbors a glycan absent in SARS-CoV2. Compared with CR3022, the binding conditions of H014 are relatively loose: $\mathrm{H} 014$ can be combined with the $\mathrm{S}$ trimer in the "one-up", "double-up" or even "three-up" conformations. Moreover, other antibodies such as n3088 and $\mathrm{n} 3130$ were also found to neutralize SARS-CoV-2 by targeting site $\mathrm{C}$ (Wu et al. 2020a, b). These small-sized single-domain antibodies fit in the lateral space between two adjacent RBD protomers and this property renders them a stronger neutralization ability than CR3022.

Some antibodies target quaternary epitopes on the top of the $\mathrm{S}$ protein that included elements of the RBDs from two adjacent S1 protomers, such as S2M11 (Poh et al. 2020) and 2-43 (Liu LH et al. 2020). Specifically, CDRH1, CDRH2 and the HCFR3 of S2M11 are docked into the RBM crevice whereas CDRH3 spans the interface between the RBM and helices (residues 339-343, 367-374) as well as residue 436 of an adjacent RBD. Cryo-EM reconstruction of the 2-43 Fab in complex with the $\mathrm{S}$ trimer at $5.8 \AA$ resolution reveals a quaternary epitope involving $\mathrm{RBD}$ from one subunit and another RBD from the next. This particular combination also results in $2-43$ being unable to bind to a single RBD.

Some late studies have shown that binding epitopes of neutralizing antibodies also exist in other regions besides the RBD. Chi et al. reported the 4A8 neutralizing antibody binds to the NTD region of the S protein (Chi et al. 2020). Structural analysis shows that the variable region of $4 \mathrm{~A} 8$ interacts with its two flexible fragments (residues G140R156 and R246-W258), thus stabilizing the structure. The interaction interface, which we named site $\mathrm{D}$, is composed of a network of extensive hydrophilic interactions (Fig. 1). In another study, Liu LH et al. (2020) reported three other NTD binding antibodies, 2-17, 5-24 and 4-8. However, the molecular motion prevented visualization of the interaction at high resolution.

Poh et al. identified two immunodominant linear B cell epitopes, S14P5 and S21P2, on the SARS-CoV-2 S glycoprotein. Peptide S14P5 is located close to the RBD (residues T562-A579) and peptide S21P2 partially overlaps with an epitope identified in a recent publication (Poh et al. 2020) and contains a part of the fusion peptide sequence (residues P818-V835). Sites containing these newly discovered epitopes are denominated site $\mathrm{E}$ and site $\mathrm{F}$, respectively (Fig. 1).

So far, most effective neutralizing antibodies are binding to RBD, especially site A. According to the existing research results, antibodies targeting site A apparently have the best antiviral activity. These antibodies not only have a stronger affinity, they are also the key to blocking receptor binding. Therefore, we believe that the vaccine design should pay more attention to the effectiveness of RBD based constructions.

We have summarized the recently discovered antigenbinding epitopes on $\mathrm{S}$ protein and proposed 6 sites $(\mathrm{A}-\mathrm{F})$, which can help us understand the diversity of antibody recognition. However, due to the conformational change of the S protein, particularly the "up" or "down" states of $\mathrm{RBD}$, the way antibodies recognize the $\mathrm{S}$ protein is more complicated than we now realize. Their recognition is dynamic, requiring both spatial and temporal moment to exert their binding and neutralizing activities. We are still in the early phase of understanding the antibody response to SARS-CoV-2. There is still much work to be done, especially the potential for antibodies from the first wave to protect against the next.

\section{Perspectives}

Numbers of clinical trials for COVID-19 are underway. Including drugs exploration, such as chloroquine, hydroxychloroquine, ribavirin, remdesivir, etc (Sanders et al. 
2020). Meanwhile, research teams from companies and universities around the world are developing more than 110 vaccines against SARS-CoV-2 based on different technologies (Thanh Le et al. 2020). The development of vaccines and drugs must have an in-depth understanding of the key SARS-CoV-2 proteins and their interactions with host factors.

Compared to drugs and vaccines, antibodies are a more direct and effective therapy during the outbreak and can be applied prophylactically. Recently, the development of antibodies for COVID-19 has entered a phase of rapid development and, hopefully, it will be possible to apply them in clinical practice soon.

At the same time, we should pay more attention to the occurrence of "antibody-dependent enhancement" (ADE) (Bloch et al. 2020). ADE is a well-recognized phenomenon whereby viral entry into cells is enhanced by virus/antibody complex binding to membrane Fc receptors or complement receptors, resulting in a worsening of the disease (Yager 2020). As several COVID-19 vaccine candidates enter human trials and the therapeutic use of convalescent plasma is explored, the debate continues amongst clinicians over whether ADE of SARS-CoV-2 infection represents a relevant concern. Antibodies can engage the host immune system through their constant domains that bind to $\mathrm{Fc}$ gamma receptors on host immune cells. These interactions can enhance immunity and help clear the pathogen or infected cells, but they can also lead to disease exacerbation in coronavirus infections. This problem would impede vaccine development but would not interfere with the clinical use of potent neutralizing antibodies that can be modified to prevent $\mathrm{Fc}$ gamma receptor interactions and thus preserve their protection against viral pathogens (Robbiani et al. 2020).

On the other hand, current genomic survey data indicate that single-nucleotide variations (SNVs) of SARS-CoV-2 are abundant. In a recent study, a team from Zhejiang University reported the functional characteristics of 11 viral isolates from COVID-19 patients, all with at least one mutation (Yao et al. 2020). This study demonstrated the functional potential of mutations currently occurring in the SARS-CoV-2 genome for affecting viral pathogenicity. Indeed, several articles reported that the mutation of aspartic acid to glycine at site 614 (D614G) of the S protein resulted in increased infectivity of SARS-CoV-2 (Daniloski et al. 2020; Korber et al. 2020; Zhang et al. 2020) and increased viral load in patients and also suggested that the prevalence of the G614 virus is related to increased mortality (Becerra-Flores and Cardozo 2020). Furthermore, in vitro studies showed that the infectivity of D614G-mutant pseudovirus on hACE2-293T and human lung epithelial cells is $\sim$ nine- and $\sim$ eight fold higher than that of wild-type SARS-CoV-2, respectively. In addition,
Daniloski et al. also found that the G614 pseudovirus has an increased ability to infect Huh7.5-ACE2, A549-ACE2, and Caco-2 cells (2.4-7.7-fold higher) (Daniloski et al. 2020). Zhang et al. further elucidated that this phenomenon is not caused by an enhanced affinity of ACE2 for the S protein but by increased stability between the $\mathrm{S} 1$ and $\mathrm{S} 2$ subunits, which elevates the number of functional S proteins on the surface of the virus, thus increasing the chances of virus-cell binding. Nonetheless, they observed that the G614 and D614 pseudoviruses are similarly susceptible to neutralizing antisera, indicating that antibodymediated control of G614 viruses is still feasible (Zhang et al. 2020).

In conclusion, mAbs targeting SARS-CoV-2 $\mathrm{S}$ protein with effective neutralizing activity are the focus of therapeutic intervention for COVID-19 development. Many studies have reported the function and structure of SARSCoV-2 neutralizing antibodies targeting the RBM region and inhibiting the association between the $\mathrm{S}$ protein and ACE2. However, the application of antibodies targeting the RBM region alone may induce drug-resistant mutations in the virus. Baum and colleagues demonstrated that under the therapeutic pressure of a single antibody, the virus produces multiple mutations that evade the blocking action of that antibody which even binds to the highly conserved regions (Baum et al. 2020). They also used the VSVSARS-CoV-2 system to screen for cocktail antibodies that could effectively prevent escaped mutants of the SARSCoV-2 because both antibodies can simultaneously noncompetitively bind to different regions of RBD. Indeed, with several antibodies that bind to different epitopes working together, virus escape would be greatly reduced and the neutralization activity would be synergistically increased.

Due to the increasing severity of the pandemic worldwide, a growing number of teams are involved in the study of SARS-CoV-2 neutralizing antibodies. However, there are noticeable variations among different assays used by different laboratories. It would be hard to directly compare the potency of antibodies from different pieces of literature. This review, which summarizes typical antibodies since the outbreak, provides researchers with an overview of the field.

Acknowledgements This work was supported by Grants from the National Science and Technology Major Project (Grant No. 2018ZX10733403).

\section{Compliance with Ethical Standards}

Conflict of interest The authors declare that they have no conflict of interest. 
Animal and Human Rights Statement This article does not contain any studies with human or animal subjects performed by any of the authors.

\section{References}

Anderson DE, Tan CW, Chia WN, Young BE, Linster M, Low JH, Tan YJ, Chen MI, Smith GJD, Leo YS, Lye DC, Wang LF (2020) Lack of cross-neutralization by SARS patient sera towards SARS-CoV-2. Emerg Microbes Infect 9:900-902

Baum A, Fulton BO, Wloga E, Copin R, Pascal KE, Russo V, Giordano S, Lanza K, Negron N, Ni M, Wei Y, Atwal GS, Murphy AJ, Stahl N, Yancopoulos GD, Kyratsous CA (2020) Antibody cocktail to SARS-CoV-2 spike protein prevents rapid mutational escape seen with individual antibodies. Science 369:1014-1018

Becerra-Flores M, Cardozo T (2020) SARS-CoV-2 viral spike G614 mutation exhibits higher case fatality rate. Int $\mathrm{J}$ Clin Pract 74:e13525

Bloch EM, Shoham S, Casadevall A, Sachais BS, Shaz B, Winters JL, van Buskirk C, Grossman BJ, Joyner M, Henderson JP, Pekosz A, Lau B, Wesolowski A, Katz L, Shan H, Auwaerter PG, Thomas D, Sullivan DJ, Paneth N, Gehrie E, Spitalnik S, Hod EA, Pollack L, Nicholson WT, Pirofski LA, Bailey JA, Tobian AA (2020) Deployment of convalescent plasma for the prevention and treatment of COVID-19. J Clin Invest 130:2757-2765

Cao Y, Su B, Guo X, Sun W, Deng Y, Bao L, Zhu Q, Zhang X, Zheng Y, Geng C, Chai X, He R, Li X, Lv Q, Zhu H, Deng W, Xu Y, Wang Y, Qiao L, Tan Y, Song L, Wang G, Du X, Gao N, Liu J, Xiao J, Su XD, Du Z, Feng Y, Qin C, Qin C, Jin R, Xie XS (2020) Potent neutralizing antibodies against SARS-CoV-2 identified by high-throughput single-cell sequencing of convalescent patients' B cells. Cell 182:73-84.e16

Chan JF, Kok KH, Zhu Z, Chu H, To KK, Yuan S, Yuen KY (2020) Genomic characterization of the 2019 novel human-pathogenic coronavirus isolated from a patient with atypical pneumonia after visiting Wuhan. Emerg Microbes Infect 9:221-236

Chi X, Yan R, Zhang J, Zhang G, Zhang Y, Hao M, Zhang Z, Fan P, Dong Y, Yang Y, Chen Z, Guo Y, Zhang J, Li Y, Song X, Chen Y, Xia L, Fu L, Hou L, Xu J, Yu C, Li J, Zhou Q, Chen W (2020) A neutralizing human antibody binds to the N-terminal domain of the Spike protein of SARS-CoV-2. Science 369:650-655

Corti D, Misasi J, Mulangu S, Stanley DA, Kanekiyo M, Wollen S, Ploquin A, Doria-Rose NA, Staupe RP, Bailey M, Shi W, Choe M, Marcus H, Thompson EA, Cagigi A, Silacci C, FernandezRodriguez B, Perez L, Sallusto F, Vanzetta F, Agatic G, Cameroni E, Kisalu N, Gordon I, Ledgerwood JE, Mascola JR, Graham BS, Muyembe-Tamfun JJ, Trefry JC, Lanzavecchia A, Sullivan NJ (2016) Protective monotherapy against lethal Ebola virus infection by a potently neutralizing antibody. Science 351:1339-1342

Daniloski Z, Guo X, Sanjana NE (2020) The D614G mutation in SARS-CoV-2 Spike increases transduction of multiple human cell types. bioRxiv 15:2020.06.14.151357

Devasenapathy N, Ye Z, Loeb M, Fang F, Najafabadi BT, Xiao Y, Couban R, Begin P, Guyatt G (2020) Efficacy and safety of convalescent plasma for severe COVID-19 based on evidence in other severe respiratory viral infections: a systematic review and meta-analysis. CMAJ 192:E745-E755

Dong N, Yang XM, Ye LW, Chen KC, Chan EWC, Yang MS, Chen S (2020) Genomic and protein structure modelling analysis depicts the origin and infectivity of 2019-nCoV, a new coronavirus which caused a pneumonia outbreak in Wuhan, China. bioRxiv 9:121
Fehr AR, Perlman S (2015) Coronaviruses: an overview of their replication and pathogenesis. Methods Mol Biol 1282:1-23

Gao Q, Bao L, Mao H, Wang L, Xu K, Yang M, Li Y, Zhu L, Wang N, Lv Z, Gao H, Ge X, Kan B, Hu Y, Liu J, Cai F, Jiang D, Yin Y, Qin C, Li J, Gong X, Lou X, Shi W, Wu D, Zhang H, Zhu L, Deng W, Li Y, Lu J, Li C, Wang X, Yin W, Zhang Y, Qin C (2020) Rapid development of an inactivated vaccine candidate for SARS-CoV-2. Science 369:77-81

Gralinski LE, Menachery VD (2020) Return of the Coronavirus: 2019-nCoV. Viruses 12

Guan WD, Mok CK, Chen ZL, Feng LQ, Li ZT, Huang JC, Ke CW, Deng X, Ling Y, Wu SG, Niu XF, Perera RA, Da Xu Y, Zhao J, Zhang LQ, Li YM, Chen RC, Peiris M, Chen L, Zhong NS (2015) Characteristics of traveler with middle east respiratory syndrome, China, 2015. Emerg Infect Dis 21:2278-2280

Hou YJ, Okuda K, Edwards CE, Martinez DR, Asakura T, Dinnon KH 3rd, Kato T, Lee RE, Yount BL, Mascenik TM, Chen G, Olivier KN, Ghio A, Tse LV, Leist SR, Gralinski LE, Schafer A, Dang H, Gilmore R, Nakano S, Sun L, Fulcher ML, LivraghiButrico A, Nicely NI, Cameron M, Cameron C, Kelvin DJ, de Silva A, Margolis DM, Markmann A, Bartelt L, Zumwalt R, Martinez FJ, Salvatore SP, Borczuk A, Tata PR, Sontake V, Kimple A, Jaspers I, O'Neal WK, Randell SH, Boucher RC, Baric RS (2020) SARS-CoV-2 reverse genetics reveals a variable infection gradient in the respiratory tract. Cell 182:429-446

Hwang WC, Lin Y, Santelli E, Sui J, Jaroszewski L, Stec B, Farzan M, Marasco WA, Liddington RC (2006) Structural basis of neutralization by a human anti-severe acute respiratory syndrome spike protein antibody, 80R. J Biol Chem 281:34610-34616

Ibarrondo FJ, Fulcher JA, Goodman-Meza D, Elliott J, Hofmann C, Hausner MA, Ferbas KG, Tobin NH, Aldrovandi GM, Yang OO (2020) Rapid decay of anti-SARS-CoV-2 antibodies in persons with mild Covid-19. N Engl J Med 383:1085-1087

Jones BE, Brown-Augsburger PL, Corbett KS, Westendorf K, Davies J, Cujec TP, Wiethoff CM, Blackbourne JL, Heinz BA, Foster D, Higgs RE, Balasubramaniam D, Wang L, Bidshahri R, Kraft L, Hwang Y, Žentelis S, Jepson KR, Goya R, Smith MA, Collins DW, Hinshaw SJ, Tycho SA, Pellacani D, Xiang P, Muthuraman K, Sobhanifar S, Piper MH, Triana FJ, Hendle J, Pustilnik A, Adams AC, Berens SJ, Baric RS, Martinez DR, Cross RW, Geisbert TW, Borisevich V, Abiona O, Belli HM, de Vries M, Mohamed A, Dittmann M, Samanovic M, Mulligan MJ, Goldsmith JA, Hsieh CL, Johnson NV, Wrapp D, McLellan JS, Barnhart BC, Graham BS, Mascola JR, Hansen CL, Falconer E (2020) LY-CoV555, a rapidly isolated potent neutralizing antibody, provides protection in a non-human primate model of SARS-CoV-2 infection. bioRxiv [Preprint]. https://doi.org/10. 1101/2020.09.30.318972

Ju B, Zhang Q, Ge J, Wang R, Sun J, Ge X, Yu J, Shan S, Zhou B, Song S, Tang X, Yu J, Lan J, Yuan J, Wang H, Zhao J, Zhang S, Wang Y, Shi X, Liu L, Zhao J, Wang X, Zhang Z, Zhang L (2020) Potent human neutralizing antibodies elicited by SARSCoV-2 infection. Nature 584:115-119

Korber B, Fischer WM, Gnanakaran S, Yoon H, Theiler J, Abfalterer W, Foley B, Giorgi EE, Bhattacharya T, Parker MD, Partridge DG, Evans CM, Freeman TM, de Silva TI, LaBranche CC, Montefiori DC (2020) Spike mutation pipeline reveals the emergence of a more transmissible form of SARS-CoV-2. bioRxiv. https://doi.org/10.1101/2020.04.29.069054

Le Thanh T, Andreadakis Z, Kumar A, Gomez Roman R, Tollefsen S, Saville M, Mayhew S (2020) The COVID-19 vaccine development landscape. Nat Rev Drug Discov 19:305-306

Liu L, Liu W, Zheng Y, Jiang X, Kou G, Ding J, Wang Q, Huang Q, Ding Y, Ni W, Wu W, Tang S, Tan L, Hu Z, Xu W, Zhang Y, 
Zhang B, Tang Z, Zhang X, Li H, Rao Z, Jiang H, Ren X, Wang S, Zheng S (2020) A preliminary study on serological assay for severe acute respiratory syndrome coronavirus 2 (SARS-CoV-2) in 238 admitted hospital patients. Microbes Infect 22:206-211

Liu LH, Wang P, Nair MS, Yu J, Rapp M, Wang Q, Luo Y, Chan JF, Sahi V, Figueroa A, Guo XV, Cerutti G, Bimela J, Gorman J, Zhou T, Chen Z, Yuen KY, Kwong PD, Sodroski JG, Yin MT, Sheng Z, Huang Y, Shapiro L, Ho DD (2020) Potent neutralizing antibodies against multiple epitopes on SARS-CoV-2 spike. Nature. 584:450-456

Liu Y, Ning Z, Chen Y, Guo M, Liu Y, Gali NK, Sun L, Duan Y, Cai J, Westerdahl D, Liu X, Xu K, Ho KF, Kan H, Fu Q, Lan K (2020) Aerodynamic analysis of SARS-CoV-2 in two Wuhan hospitals. Nature 582:557-560

Long QX, Tang XJ, Shi QL, Li Q, Deng HJ, Yuan J, Hu JL, Xu W, Zhang Y, Lv FJ, Su K, Zhang F, Gong J, Wu B, Liu XM, Li JJ, Qiu JF, Chen J, Huang AL (2020) Clinical and immunological assessment of asymptomatic SARS-CoV-2 infections. Nat Med 26:1200-1204

Lv Z, Deng YQ, Ye Q, Cao L, Sun CY, Fan C, Huang W, Sun S, Sun Y, Zhu L, Chen Q, Wang N, Nie J, Cui Z, Zhu D, Shaw N, Li XF, Li Q, Xie L, Wang Y, Rao Z, Qin CF, Wang X (2020) Structural basis for neutralization of SARS-CoV-2 and SARSCoV by a potent therapeutic antibody. Science 369:1505-1509

Mackay IM, Arden KE (2015) MERS coronavirus: diagnostics, epidemiology and transmission. Virol J 12:222

Markus H, Hannah KW, Nadine K, Marcel M, Christian D, Pöhlmann S (2020) The novel coronavirus 2019 (2019-nCoV) uses the SARS-coronavirus receptor ACE2 and the cellular protease TMPRSS2 for entry into target cells. bioRxiv. https://doi.org/10. $1101 / 2020.01 .31 .929042$

Okba NMA, Müller MA, Li WT, Wang CY, Haagmans BL (2020) Severe acute respiratory syndrome coronavirus 2-specific antibody responses in coronavirus disease patients. Emerg Infect Dis 26:1478-1488

Ou X, Liu Y, Lei X, Li P, Mi D, Ren L, Guo L, Guo R, Chen T, Hu J, Xiang Z, Mu Z, Chen X, Chen J, Hu K, Jin Q, Wang J, Qian Z (2020) Characterization of spike glycoprotein of SARS-CoV-2 on virus entry and its immune cross-reactivity with SARS-CoV. Nat Commun 11:1620

Pinto D, Park YJ, Beltramello M, Walls AC, Tortorici MA, Bianchi S, Jaconi S, Culap K, Zatta F, De Marco A, Peter A, Guarino B, Spreafico R, Cameroni E, Case JB, Chen RE, Havenar-Daughton C, Snell G, Telenti A, Virgin HW, Lanzavecchia A, Diamond MS, Fink K, Veesler D, Corti D (2020) Cross-neutralization of SARS-CoV-2 by a human monoclonal SARS-CoV antibody. Nature 583:290-295

Poh CM, Carissimo G, Wang B, Amrun SN, Lee CY, Chee RS, Fong SW, Yeo NK, Lee WH, Torres-Ruesta A, Leo YS, Chen MI, Tan SY, Chai LYA, Kalimuddin S, Kheng SSG, Thien SY, Young BE, Lye DC, Hanson BJ, Wang CI, Renia L, Ng LFP (2020) Two linear epitopes on the SARS-CoV-2 spike protein that elicit neutralising antibodies in COVID-19 patients. Nat Commun 11:2806

Prabakaran P, Gan J, Feng Y, Zhu Z, Choudhry V, Xiao X, Ji X, Dimitrov DS (2006) Structure of severe acute respiratory syndrome coronavirus receptor-binding domain complexed with neutralizing antibody. J Biol Chem 281:15829-15836

Robbiani DF, Gaebler C, Muecksch F, Lorenzi JCC, Wang Z, Cho A, Agudelo M, Barnes CO, Gazumyan A, Finkin S, Hagglof T, Oliveira TY, Viant C, Hurley A, Hoffmann HH, Millard KG, Kost RG, Cipolla M, Gordon K, Bianchini F, Chen ST, Ramos V, Patel R, Dizon J, Shimeliovich I, Mendoza P, Hartweger H, Nogueira L, Pack M, Horowitz J, Schmidt F, Weisblum Y, Michailidis E, Ashbrook AW, Waltari E, Pak JE, Huey-Tubman KE, Koranda N, Hoffman PR, West AP Jr, Rice CM,
Hatziioannou T, Bjorkman PJ, Bieniasz PD, Caskey M, Nussenzweig MC (2020) Convergent antibody responses to SARS-CoV-2 in convalescent individuals. Nature 584:437-442

Rogers TF, Zhao F, Huang D, Beutler N, Burns A, He WT, Limbo O, Smith C, Song G, Woehl J, Yang L, Abbott RK, Callaghan S, Garcia E, Hurtado J, Parren M, Peng L, Ramirez S, Ricketts J, Ricciardi MJ, Rawlings SA, Wu NC, Yuan M, Smith DM, Nemazee D, Teijaro JR, Voss JE, Wilson IA, Andrabi R, Briney B, Landais E, Sok D, Jardine JG, Burton DR (2020) Isolation of potent SARS-CoV-2 neutralizing antibodies and protection from disease in a small animal model. Science 369:956-963

Sanders JM, Monogue ML, Jodlowski TZ, Cutrell JB (2020) Pharmacologic treatments for coronavirus disease 2019 (COVID-19): a review. JAMA 323:1824-1836

Shang J, Ye G, Shi K, Wan Y, Luo C, Aihara H, Geng Q, Auerbach A, Li F (2020) Structural basis of receptor recognition by SARSCoV-2. Nature 581:221-224

Shi R, Shan C, Duan X, Chen Z, Liu P, Song J, Song T, Bi X, Han C, Wu L, Gao G, Hu X, Zhang Y, Tong Z, Huang W, Liu WJ, Wu G, Zhang B, Wang L, Qi J, Feng H, Wang FS, Wang Q, Gao GF, Yuan Z, Yan J (2020) A human neutralizing antibody targets the receptor binding site of SARS-CoV-2. Nature 26:1422-1427

Tan Y, Liu F, Xu X, Ling Y, Huang W, Zhu Z, Guo M, Lin Y, Fu Z, Liang D, Zhang T, Fan J, Xu M, Lu H, Chen S (2020) Durability of neutralizing antibodies and T-cell response post SARS-CoV-2 infection. Front Med 5:1-6

Walls AC, Park YJ, Tortorici MA, Wall A, McGuire AT, Veesler D (2020) Structure, function, and antigenicity of the SARS-CoV-2 spike glycoprotein. Cell 181:281-292

Wan JK, Xing SH, Ding LF, Wang YH, Zhu DD, Rong BW, Wang SQ, Chen K, He CX, Yuan SH, Qiu CL, Zhao C, Zhang XY, Wang XX, Lu YN, Xu JQ, Lan F (2020) Human IgG cell neutralizing monoclonal antibodies block SARS-CoV-2 infection. Cell Rep 32:107918

Wang C, Li W, Drabek D, Okba NMA, van Haperen R, Osterhaus A, van Kuppeveld FJM, Haagmans BL, Grosveld F, Bosch BJ (2020) A human monoclonal antibody blocking SARS-CoV-2 infection. Nat Commun 11:2251

Wang HY, Hou X, Wu X, Liang T, Zhang XM, Wang D, Teng F, Da JY, Duan H, Guo SB, Li YZ, Yu X (2020) SARS-CoV-2 proteome microarray for mapping COVID-19 antibody interactions at amino acid resolution. ACS Cent Sci. https://doi.org/10. 1101/2020.03.26.994756

Wang P, Liu L, Nair MS, Yin MT, Luo Y, Wang Q, Yuan T, Mori K, Solis AG, Yamashita M, Purpura LJ, Laracy JC, Yu J, Sodroski J, Huang YX, Ho DD (2020) SARS-CoV-2 neutralizing antibody responses are more robust in patients with severe disease. Emerg Microbes Infect 9:2091-2093

World Health Organization (WHO) (2020) Coronavirus disease (COVID-19) pandemic. https://www.who.int/emergencies/dis eases/novel-coronavirus-2019/situation-reports/

Wrapp D, De Vlieger D, Corbett KS, Torres GM, Wang N, Van Breedam W, Roose K, van Schie L, Hoffmann M, Pohlmann S, Graham BS, Callewaert N, Schepens B, Saelens X, McLellan JS (2020a) Structural basis for potent neutralization of betacoronaviruses by single-domain Camelid antibodies. Cell 181:1004-1015

Wrapp D, Wang N, Corbett KS, Goldsmith JA, Hsieh CL, Abiona O, Graham BS, McLellan JS (2020b) Cryo-EM structure of the 2019-nCoV spike in the prefusion conformation. Science 367:1260-1263

Wu YL, Li C, Xia S, Tian X, Kong Y, Wang Z, Gu C, Zhang R, Tu C, Xie Y, Yang Z, Lu L, Jiang S, Ying T (2020) Identification of human single-domain antibodies against SARS-CoV-2. Cell Host Microbe 27:e895 
Wu Y, Wang F, Shen C, Peng W, Li D, Zhao C, Li Z, Li S, Bi Y, Yang Y, Gong Y, Xiao H, Fan Z, Tan S, Wu G, Tan W, Lu X, Fan C, Wang Q, Liu Y, Zhang C, Qi J, Gao GF, Gao F, Liu L (2020b) A noncompeting pair of human neutralizing antibodies block COVID-19 virus binding to its receptor ACE2. Science 368:1274-1278

Xu X, Sun J, Nie S, Li H, Kong Y, Liang M, Hou J, Huang X, Li D, Ma T, Peng J, Gao S, Shao Y, Zhu H, Lau JY, Wang G, Xie C, Jiang L, Huang A, Yang Z, Zhang K, Hou FF (2020) Seroprevalence of immunoglobulin $\mathrm{M}$ and $\mathrm{G}$ antibodies against SARS-CoV-2 in China. Nat Med 26:1494

Yager EJ (2020) Antibody-dependent enhancement and COVID-19: moving toward acquittal. Clin Immunol 217:108496

Yao HP, Lu XY, Chen Q, Xu KJ, Chen Y, Cheng LF, Liu FM, Wu ZG, Wu HB, Jin CZ, Zheng M, Wu NP, Jiang C, Li L (2020) Patient-derived mutations impact pathogenicity of SARS-CoV-2. medRxiv[Preprint]. https://doi.org/10.1101/2020.04.14. 20060160

Ying T, Li H, Lu L, Dimitrov DS, Jiang S (2015) Development of human neutralizing monoclonal antibodies for prevention and therapy of MERS-CoV infections. Microbes Infect 17:142-148

Yuan M, Liu H, Wu NC, Lee CD, Zhu X, Zhao F, Huang D, Yu W, Hua Y, Tien H, Rogers TF, Landais E, Sok D, Jardine JG, Burton DR, Wilson IA (2020a) Structural basis of a shared antibody response to SARS-CoV-2. Science 369:1119-1123

Yuan M, Wu NC, Zhu X, Lee CD, So RTY, Lv H, Mok CKP, Wilson IA (2020b) A highly conserved cryptic epitope in the receptor binding domains of SARS-CoV-2 and SARS-CoV. Science 368:630-633
Zaki AM, van Boheemen S, Bestebroer TM, Osterhaus AD, Fouchier RA (2012) Isolation of a novel coronavirus from a man with pneumonia in Saudi Arabia. N Engl J Med 367:1814-1820

Zhang L, Jackson CB, Mou H, Ojha A, Rangarajan ES, Izard T, Farzan M, Choe H (2020) The D614G mutation in the SARS$\mathrm{CoV}-2$ spike protein reduces $\mathrm{S} 1$ shedding and increases infectivity. bioRxiv 2020.06.12.148726

Zhao J, Yuan Q, Wang H, Liu W, Liao X, Su Y, Wang X, Yuan J, Li T, Li J, Qian S, Hong C, Wang F, Liu Y, Wang Z, He Q, Li Z, He B, Zhang T, Fu Y, Ge S, Liu L, Zhang J, Xia N, Zhang Z (2020) Antibody responses to SARS-CoV-2 in patients of novel coronavirus disease 2019. Clin Infect Dis 71:2027-2034

Zhou P, Yang XL, Wang XG, Hu B, Zhang L, Zhang W, Si HR, Zhu Y, Li B, Huang CL, Chen HD, Chen J, Luo Y, Guo H, Jiang RD, Liu MQ, Chen Y, Shen XR, Wang X, Zheng XS, Zhao K, Chen QJ, Deng F, Liu LL, Yan B, Zhan FX, Wang YY, Xiao GF, Shi ZL (2020) A pneumonia outbreak associated with a new coronavirus of probable bat origin. Nature 579:270-273

Zost SJ, Gilchuk P, Case JB, Binshtein E, Chen RE, Nkolola JP, Schäfer A, Reidy JX, Trivette A, Nargi RS, Sutton RE, Suryadevara N, Martinez DR, Williamson LE, Chen EC, Jones T, Day S, Myers L, Hassan AO, Kafai NM, Winkler ES, Fox JM, Shrihari S, Mueller BK, Meiler J, Chandrashekar A, Mercado NB, Steinhardt JJ, Ren K, Loo YM, Kallewaard NL, McCune BT, Keeler SP, Holtzman MJ, Barouch DH, Gralinski LE, Baric RS, Thackray LB, Diamond MS, Carnahan RH, Crowe JE Jr (2020) Potently neutralizing and protective human antibodies against SARS-CoV-2. Nature 584:443-449 